原

\title{
乳癌局所皮膚再発の臨床的検討
}

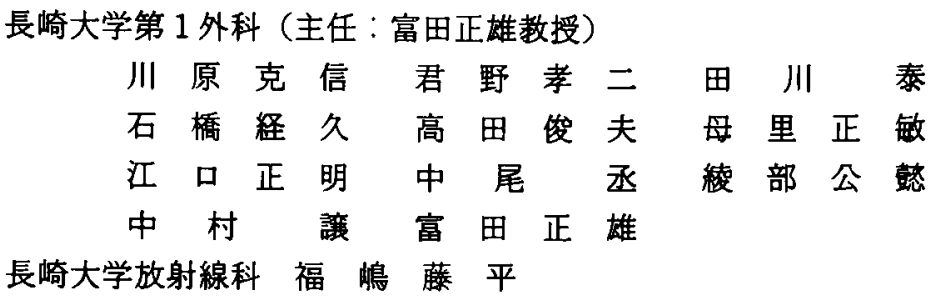

\section{CLINICAL STUDY OF THE LOCAL SKIN RECURRENCE OF BREAST CANCER}

Katsunobu KAWAHARA, Koji KIMINO, Yutaka TAGAWA, Tsunehisa ISHIBASHI Toshio TAKADA, Mashatoshi MORI, Masaaki EGUCHI, Susumu NAKAO Hiroyoshi AYABE, Yuzuru NAKAMURA and Masao TOMITA

The First Department of Surgery, Nagasaki University School of Medicine, Nagasaki, Japan Tohei FUKUSHIMA

Department of Radiology, Nagasaki University School of Medicine, Nagasaki, Japan

1955年より1981年までに教室で䍩験した乳癌根治術後の局所皮席再発症例について臨 床的に検討した。

局所皮革再発の頻度は，同期間内における根治術施行例390例中15例3.8\%で，結節型 6 例，散布型 6 例，びまん浸潤型 2 例，再発形式不明 1 例であった。

$\mathrm{T}$ よびn因子別では，結節型は $\mathrm{T}_{2}, \mathrm{n}_{0}$ 症例に，また散布型，びまん浸潤型は $\mathrm{T}_{3}, \mathrm{~T}_{4}$ ，

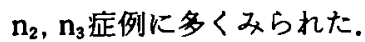

組織型別には，硬癌に最も多く8.6\%，次いで䯣梯腺管癌 $4.6 \%$, 乳頭腺管癌 $2.2 \%$ あっ た.

乳癌根治術より局所皮凮再発々現までの無病期間は結節型では平均27.6カ月，また散 布型では平均 16.8 力 月で, 結節型, 散布型の 1 年末満再発例は 11 例中 1 例の 2であるが, びまん浸潤型では無病期間は極めて短く，2 例ともに 2 力月以内であった。

治療は，結節型では生検をかねて腫瘤を切除後，6例中 4 例に胸壁に放射線照射を行 い，遠隔転移のみられない㱏例では15〜24カ月再々発をみない，又散布型では 6 例に放 射線照射を行い，4 例に畽瘤の消失ないし縮小を認め放射線療法の有効性をらかがい得 たが、びまん漫潤型では照射野外への腫瘤の拡大と遠隔転移の出現により十分な照射を 行うことができなかった。

遠隔転移は10例にみられ，らち肺，胸膜，骨転移が多く，結節型にくらへ，散布型， びまん漫潤型の予後は不良であった。

来引用語：乳癌局所皮庙再発，結節型，散布型，びまん浸潤型

はじめに

原発性乳癌根治衍後の局所皮闻発は，患者に与え る精神的苦痛と，しばしば併存する遠隔転移により， その治療に苦虑することがある。
教室では主として局所皮庙再発に対し，放射線療法 を中心とした治療を行ってきた。今回これらの症例を 臨床的に検討し, 治療上の問題点について, 若干の考 察を加之報告する。 
著者らが対象とした局所皮店再発とは，第35回乳癌 研究会規約委員会の決定に従い，結節型，散布型，び まん浸潤型の 3 型に分類した。

\section{症 例}

1955年より1981年末むでに教室で根治術を行った原 発性乳癌は390例で，そのうち局所皮庙再発は15例 （3.8\%）であった（表 1$).$

再発形式は，結節型 7 例，散布型 5 例，びまん浸潤 型 2 例，および形式不明 1 例である. 発生部位は，創 痗痕に一致するすの 5 例, 移殖皮咸片 1 例, 胸骨旁照 射野内 1 例, 内側皮弁 2 例, 両側皮弁 3 例, 不明 2 例 で，外側皮并のみの再発はない（表 1)。

原発乳癌の $\mathrm{Tnm}$ 病期は（表 2)，結節型では I 期 4 例, II 期 2 例で III, IV 期はなく，散布型では I 期 2 例。 II 期はなく III 期 3 例，IV 期 1 例，びまん浸潤型では 2 例とも IV 期であった. T因子別にみると, 結節型で は $T_{1} 2$ 例， $T_{2} 4$ 例で， $T_{3}, T_{4}$ はなく，散布型では $T_{1}$ はなく $\mathrm{T}_{2} 3$ 例, $\mathrm{T}_{3} 1$ 例, $\mathrm{T}_{4} 2$ 例で, びまん浸潤型では 2 例ともに $T_{4}$ で, 不明例は $T_{3}$ であった。 $\mathrm{n}$ 因子別にみ ると, 結節型では $\mathrm{n}_{0} 4$ 例, $\mathrm{n}_{1} \beta 2$ 例で $\mathrm{n}_{2}, \mathrm{n}_{\mathbf{3}}$ はなく, 散 布型では $n_{0} 3$ 例, $n_{1} \beta 1$ 例, $n_{2} 2$ 例, びまん浸潤型は

\section{表 1 局所皮宙再钅の形式，再無部位}

\begin{tabular}{cc}
$\begin{array}{c}\text { primary breast cancer } \\
\text { local skin recurrent } \\
\text { type of local skin recurrent }\end{array}$ & $\begin{array}{r}390 \text { cases } \\
15 \text { cases }\end{array}$ \\
\hline solid & 7 \\
multiple & 5 \\
diffuse & 2 \\
unknown & 1 \\
location of skin recurrent \\
\hline operations scar & 5 \\
skin graft & 1 \\
parasternal & 1 \\
inner flap & 2 \\
outer flap & 0 \\
both flaps, graft & 4 \\
unknown & 2
\end{tabular}

各々 $\mathrm{n}_{2}, \mathrm{n}_{3}$ であった，結節型は比較的腫瘤径が小さく， また散布型，びまん浸潤型では腫瘤径が大きく、リン 八節転移の高度な例に，局所皮虚再発が多くみられる ようである。

原発乳癌の手術々式は(表 3 ), 定型乳切 4 例，非定 型乳切 4 例（小胸筋保存乳切 2 例, 大胸筋保存乳切 2 例)，抬大乳切 7 例(Ps 抎大乳切 6 例, $P_{s}, S_{c}$ 払大乳切 1 例)である。皮切は皮㖇固定のない昜合は腫瘤绿よ り $3 \mathrm{~cm}$ ，皮唐固定のみられる場合は $5 \mathrm{~cm}$ 離すことを原 則としている.

組織型では（表 2)，原発乳癌311例のらち局所皮用 再発は硬癌に最も多く8.6\% (6/69), 次いで椈様腺管 癌 $4.6 \%(5 / 109)$, 乳頭腺管癌 $2.2 \%(2 / 89)$ であった。 原発乳癌の根治術より局所皮庙再発々現までの無病 期間（表 4)は，結節型では 9 カ月ないし54力月，平 均27.6力月，また散布型では15カ月ないし27カ月，平 均16.8力月で、結節型, 散布型の 1 年末満再発例は11 例中 1 例の又であるが、びまん浸潤型では無病期間は 極めて短かく，2例ともに 2 カ月以内であった。

遠隔転移は(表 5 )，観察期間 2 力月ないし51カ月で 15例中10例にみられ，その5ち9例は 6 カ月以内で あった。転移㼨器は, 肺, 胸膜 5 例, 肝, 腹膜 2 例, 骨 4 例(腰椎 3 , 助骨 1 ), 頝部リンハ節 1 例, 対側乳 房 1 例である。遠隔転移のみられない症例は 4 例て， 5ち 3 例が結節型, 1 例が散布型である.

局所再発巣に対する治療は，結節型（表 6) では生 検をかねて尾瘤の剔出術を行った後，5例に放射線療 法を行った。 4 例に Liniac 電子線あるいは Tel- ${ }^{60} \mathrm{Co}$, 1 回200rad, 週 5 回, 総量4,500 5,000rad 照射 $し$, 15〜24力月再々発をみていない，1例はLiniac 2,000 $\operatorname{rad}$ 照射した頃より肺, 胸膜, 䅡部リンバ節転移が出現 したため,やむなく中止したが 9 カ月目に死亡した。 腫瘤切除後照射を行わなかった 2 例のうち 1 例は肺枟 移が併存し，切除部に難治性の皮庙漫愓の形成が如ら れ，5 Fu軟弯塗布を続け，特に增大の傾向はみられな かったか， 8 カ月目胸膜轻移をきたして死亡した．残

表 2 局所皮届再発症例15例の Tnm 病期，および組維型

\begin{tabular}{|c|c|c|c|c|c|c|c|c|}
\hline \multicolumn{2}{|c|}{$T \cdot$ factor } & \multicolumn{2}{|c|}{ n-factor } & \multicolumn{2}{|c|}{ Tnm stage } & \multicolumn{3}{|c|}{ Histological type } \\
\hline T 0 & 0 & no & 7 & I & 6 & papillary tubular ca. & 2 & $2.2 \%(2 / 89)$ \\
\hline $\mathrm{T} 1$ & 2 & $\mathrm{n} 1 \alpha$ & $\mathbf{0}$ & II & 2 & medullary tubular ca. & 5 & $4.6 \%(5 / 109)$ \\
\hline $\mathrm{T} 2$ & 7 & $\mathrm{nl} \beta$ & 4 & III & 4 & scirrhous ca. & 6 & $8.6 \%(6.69)$ \\
\hline T 3 & 2 & $\mathrm{n} 2$ & 3 & IV & 3 & unknown & 2 & \\
\hline T 4 & 4 & n3 & 1 & & & & & \\
\hline
\end{tabular}


表 3 乳棈桹浦式（局所再発症例）

standard radical mastectomy

modified radical mastectomy

$\mathrm{Br} \mathrm{Ax} \mathrm{Mj}$

patey's operation

Extended radical mastectomy

parasternal dessection

parasternal \& supraclavicular 1

dissection

表4根治通後，局所皮启再無々現までの無病期間

\begin{tabular}{lr}
\hline solid & $27.66 \pm 17.36 \mathrm{M}$ \\
multiple & $16.83 \pm 6.83 \mathrm{M}$ \\
diffuse & $1.5 \pm 0.71 \mathrm{M}$ \\
unknown & $6 \mathrm{M}$ \\
\hline
\end{tabular}

表 5 遠隔転移部位（局所再発症例）

\begin{tabular}{|c|c|}
\hline distant metastasis (-) & 4 \\
\hline$(+)$ & 10 \\
\hline lung, pleura & 5 \\
\hline vertebra, rib & 4 \\
\hline liver, peritoneum & 2 \\
\hline cervical nodes & 1 \\
\hline contralateral breast & 1 \\
\hline unknown & 1 \\
\hline
\end{tabular}

る 1 例は73歳という高龄を考虑し，腫瘤切除部の皮有 の追加切除にとどめ，2 カ月現在再々発をみない，散 布型では（表 7)，全例に Liniac 電子線5,000 rad の照 射を行った，2例に腫瘤の消失をみとめ，5ち 1 例は 51 力月癌性腹膜炎で死亡し，1例は 9 力月現在再々発 および遠隔転移をみない，2例に腫瘤の樎小，一部消 失がみられたか，1例は肺転移，1例は対側乳房転移 をきたしLiniac 5,000rad追加照射を行って現在経過 舅察中である. 残る1例は全く局所奻果はみられず， 2 カ月後肝，腰椎転移をきたして死亡した。びまん浸 潤型（㤗 8 ）の1例は，Liniac 電子線1,000 rad 照射し た頃より胸膜，肺転移が出現したため照射を中止した が，小結節状の腫瘤はびまん性に広範囲に払大し，6 ケ月後死亡した。また残る 1 例は，術後 1 カ月目，照 射を開始した頃より創部皮席に大小の結節状腫瘤が出 現し，背部，肩甲部，頝部にびまん性に拡大し， 5 カ 月目肺，骨転移で死亡した。再発形式不明例は転医し たため照射を行っていないが， 3 カ月後肺，骨転移で 死亡した。

局所再発後の累積生存率は，6力月生存率 $78.5 \%$,

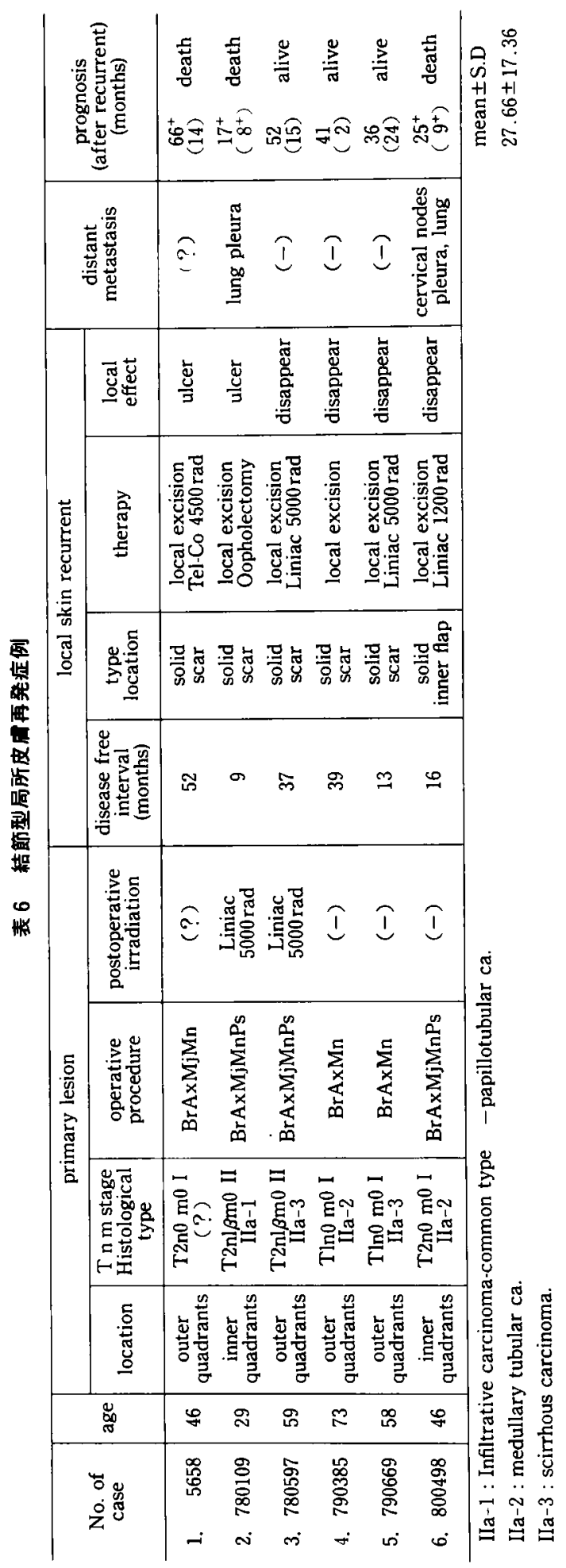



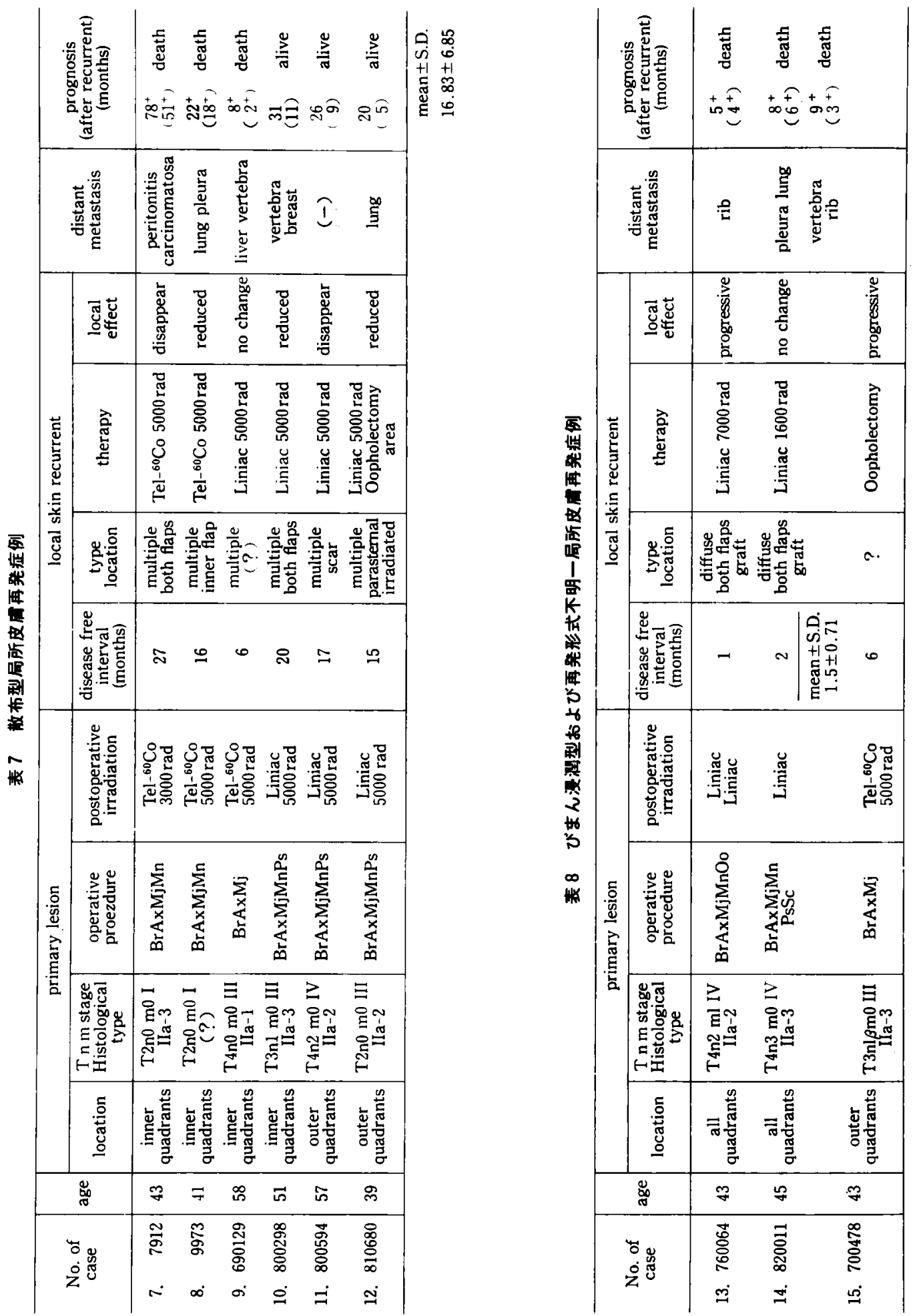
1 年生存率 $40.4 \%$ で, 5 年以上生存例はない。 考察

局所皮而再発の頻度は5 - 17.5\% ${ }^{122}$ と言われ，本邦 では第36回乳癌研究会 フンヶート集計によると $6.3 \%^{3)}$ である。

局所皮届再発の原因は，(1) 不十分な皮席切離による 癌細胞の遗残 (Conway)4), (2) 癌細胞の術野への implantation (Haagensen) ${ }^{5)}$, (3) 助間および胸骨旁リン 八管閉塞による retrograde dissemination (Auchincloss) $)^{6)}$, (4) 血行性転移7) とれている。 Zimmerman ${ }^{8}$ によると，孤立性の結節が手術疫痕に 沿って出現する場合は癌細胞の implantationが原因 で，多数の小結節がびまん性にみられる場合は retrograde dissemination Кよるものとしている。

初回手術時のリンバ節転移と局所皮席再発との関俰 は，Dao", Haagensen ${ }^{10)}$, Donegan ${ }^{11}$ によれば，リン 八節転移の高度な例に局所皮革再発が多く，特に播種 状再発が多くみられるとされ，教室例です，結節型で は $\mathrm{n}_{0}$ が 4 例で $\mathrm{n}_{2}, \mathrm{n}_{3}$ はないが，散布型では $\mathrm{n}_{1} \beta, \mathrm{n}_{2}$, び まん浸溜型は $\mathrm{n}_{2}, \mathrm{n}_{3}$ であった。

原発巣の組織型は，乳癌研究会アンケートによる全 国集計3)では硬癌の頻度が最も高く8.8\%次いで䯣様 腺管癌 $7.3 \%$ ，乳頭腺管癌 $4.2 \%$ である，教室例です硬 癌における頻度が最も高く，髄様腺管癌，乳頭腺管癌 の順であった。

原発乳癌術後，局所皮局再発々現に至るまでの無病 期間は 2 年以内が多く, $\mathrm{Chu}^{122}$ は 2 年以内 $75 \%$ ，平均 1.8年であったとし，教室例でも13例中 10 例が 2 年以内 の再発である．また局所病変の進展しているものほど 無病期間は短かく，乳癌研究会フンケート全国集計 ${ }^{3)}$ によれば，びまん浸閏型では 1 年以内 $46.3 \% ， 2$ 年以 内 $76.9 \%$ ，散布型では 1 年以内 $31.9 \% ， 2$ 年以内 $69.0 \%$ ，結節型では 1 年以内 $26.0 \% ， 2$ 年以内 $50.4 \%$ で，びをん浸潤型，散布型では70\%以上が 2 年以内の 再発である。

局所皮屚再発例は遠隔転移を合併することが多く， Marshall ${ }^{133}$ は57例中55例が遠隔転移を伴っており，局 所再発自体が臨床上問題となる例は少いとしている. 教室例では 1 年末满再発例 5 例はすべて 3 力月以内 に，また $1 \sim 2$ 年以内再発例 5 例中 2 例は 3 力月以内 に遠隔転移がみられ，転移荗器は肺胸膜，骨が主体で あった。

放射線治療は局所皮后再発巣に対する局所療法とし て有効な手段であり，Liniac 電子線200rad/日，週 5
日，総量4,000 5,000 rad 照射 ${ }^{12)}$ されことが多い，局 所奻果について $\mathrm{Chu}^{121}$ は, complete response $64 \%$, partial response27\%，全体で91\%に有効であったと し，伊藤 ${ }^{44}$ は播種型で $100 \%$ ，限局型で $56 \%$ に腫瘤の消 失をみたとしている。

放射線療法啳の 5 生率については, Bedwinek ${ }^{15}$ / は 13\% (34/129) で，そのうち disease-free interval が 2 年以上では $56 \% ， 2$ 年以内で $17 \%$ ，また再発巣の大 きさ $1 \mathrm{~cm}$ 以下 $51 \%, 1 \mathrm{~cm}$ 以上あるいは散布型では $20 \%$ であったとし，局所皮成再発後の予後を左右する因子 として，(1) 抓立型，(2) 腫瘤の大きさが $1 \mathrm{~cm}$ 以下，(3) disease-free interval が 2 年以上であることを挙げ， (1)(2)(3条件をすべて有する症例の 5 生率は $53 \%$ \% いずれの条件も有しない症例に 5 年以上生存例はな かったとしている。また Chu的は complete response をみた症例の 5 生率は $26 \%$, partial response では9\% であったとしている。

局所再発巣の外科的切除を行い得た症例の手術成續 は, Nieminen ${ }^{16)}$ は26例中 3 例に再々発をみず, 10例に 局所皮席再々発，7例にリン八節再発，15例に遠隔転 移をみたとし，局所皮庙再々発までの期間は平均 $15.3 \pm 3.4$ 力月, 遠隔転移発現は12.9土3.5力月で, 2 年生存率77\%とし，Urban ${ }^{177}$ は66\%，5生率 $\mathrm{Chu}^{122} 21 \%$, Haagensen ${ }^{18)} 12 \%$ としていろ.いずれにし ても遠隔転移の出現しない症例では，予後は必ずしも 悪くない. Marshall14)は，局所再発のみによる死亡は 107例中 1 例のみで，はとんどの例が遠隔転移によるも のとしている.

術後照射と局所皮庙再発との関保については一致し た見解はなく，大川199は照射部位における局所皮席再 発は照射野に限局し， superficial layerにみられるの に対し，非照射例では胸壁あるいは手術創洀痕に沿っ た結節を形成してくるとし，照射例では照射野内の生 き残った癌細胞の散布が容易になるためと言 ら。 Fisher ${ }^{201}$ は術後照射群では遠隔転移率は低いか，局所 再発率は非照射群と差はなく，さらに長期の観察が必 要とし，Cole ${ }^{211}$ は stage I, II の症例に術後予防的照射 を行ったところ，局所再発率が19.9\%から11.5\%に減 少したとして一応の評価を与えているが，4例に照射 野に限局した局所皮成再発をみたことから，予防的術 後照射は症例を慎重に選択すべきであるとしている。 また小山䄈予防照射は局所皮后再発を防止するとは 言い難いとしている，教室例です 1 例に，予防的照射 を行った胸骨旁照射野内皮店に散布型の局所皮底再発 
をみており，無用の照射はできるだけ避けるべきと思 われる。

$$
\text { まとめ }
$$

1955年より1981年までに教室で経験した乳癌局所皮 庙再発症例について臨床的に検討した，局所皮席再発 の頻度は，同期間内における原発乳癌根治術施行例 390 例中15例 $3.8 \%$ を占めた。結節型の局所皮府再発は, 生 模をかねて腫痹を切除後，胸壁に放射線照射を行い， 遠隔転移のみられない症例では5２4カ月再々発をみ ない. 散布型では放射線照射例 6 例中 4 例に尰瘤の消 失ないし縮小を認め，放射線療法の有効性をらかかい， 得たが，びまん浸潤型では照射野外への腫瘤の扗大上 遠隔転移の出現により，十分な照射を行うことが困難 であった。

死因は遠隔転移に上るるので，肺，胸膜，骨転移が 多く，局所皮闻再発自体が病態を增悪させる因子とは なり難いが，再発形式によって予啳の推測が可能で， 結節型にくらぺ，散布型，びまん浸潤型の予後は不良 である。

組縺型別には硬癌におりる局所皮席再発の頻度が最 も高く 8.6\%であった。

\section{文嗝}

1) Weichselbaum, R.R., Marck, A. and Hellman, S.: The role of postoperation irradiation in carcinoma of the breast. Cancer, 37: 2682 -2690, 1976.

2) Deck, K.B. and Kern, W.H.: Local recurrence of the breast cancer. Arch. Surg., 111 : 323-325, 1976.

3）第36回. 乳癌研究会アンケート集計(大阪), 1982.

4) Conway, H. and Neumann, C.G. : Evaluation of skin grafting in the technique of radical mastectomy in relation to local recurrence of carcinoma. Surg. Gynecol. Obstet., 88 : 45-49, 1949.

5) Haagensen, C.D.: Diseases of the breast. Philadelphia, W.B. Saunders Company, 1956.

7）和田富雄，高橋良和。西沢征夫他：乳透の局所再発 とその治療方針，日癌治誌，15(2)：142-149， 1980.

8) Zimmerman, K.W., Montague, E.D. and Fletcher, G.H.: Frequency, anatomical distribution and management of local recurrences after definitive therapy for breast cancer. Cancer, 19 : 67-74, 1966.

9) Dao, T.L. and Kovaric, J.: Incidence of pul- monary and skin metastasis in women with breast cancer who received post-operative irradiation. Surgery, 52: 203-212, 1962.

10) Haagensen, C.D. and Stout, A.P.: Carcinoma of the breast-II. Criteria of operability. Ann. Surg., 118: 859-870, 1032-1051, 1943.

11) Donegan, W.L., Perez-Mesa, C.M. and Watoson, F.R.: A biostatistical study of locally recurrent breast carcinoma. Surg. Gynecol. Obstet., $122: 529-540,1966$.

12) Florence, C.H., Chu, Fang-Jen Lin, Jae Ho Kim, et al.: Locally recurrent carcinoma of the breast, result of radiation therapy. Cancer, 37 : 2677-2681, 1976.

13) Marshall, K.A., Redferm, A. and Cady, B.: Local recurrences of carcinoma of the breast. Surg. Gynecol. Obstet., 139 : 406-408, 1974.

14）伊藤一郎, 宮石和夫, 岡崎 篤他: 電子線週 2 回分 割照射法による局所再発乳癌の治療成统，日本放 射湶学会誌, 38(3)：221-229，1978.

15) John M. Bedwinek, Barbara Fineberg, A.B., Jeannette Lee, et al.: Prognostic indications in patients with isolated local-regional recurrence of breast cancer. Cancer, $47: 2232-2235$, 1981.

16) Nieminen, S., Hietanen, T. and Nordman, E., et al. : Surgical treatment of local recurrences of breast carcinoma in the skin and subcutaneous tissues. Acta. Chir. Scand., 145 : 463-465, 1979.

17) Shah, J.P. and Urban, J.A.: Full thickness chest wall resection for recurrent breast carcinoma involving the bony chest wall. Cancer, $35: 567-573,1975$.

18) Haagensen, C.D.: The choice of treatment for operable carcinoma of the breast. Surgery, 76 : 685-714, 1974.

19）大川昌権, 但元 博, 荒居竜婎他：乳癌街後照射の 治療成續，疾の臨床，27(10)：1196-1199，1981.

20) Fisher, B., Slack, N.H., Cavanaugh, P.T., et al.: Postoperative radiotherapy in the treatment of breast cancer: Result of the NSABP clinical trial. Ann. Surg., 172 : 711-732, 1970.

21) Cole, H. and Haln an, K.E. : Facilitation of tumor spread in irradiation tissue after prophylactic post operative X-ray therapy for breast cancer. Clin. Radiol., 22 : 133-135, 1971.

22）小山博記, 和田富雄, 高唡良和他：乳癌行後照射の 意義一照射部位に再発した症例の検討，癌の臨床， $22: 579-583,1976$. 